\title{
NOTE
}

\section{Nutrient input by seabirds to the forest on a coral island of the Great Barrier Reef}

\author{
W. G. Allaway ${ }^{1}$ and A. E. Ashford ${ }^{2}$ \\ 1 School of Biological Sciences, the University of Sydney, NSW 2006. Australia \\ 2 School of Botany, the University of New South Wales, Kensington, NSW 2033, Australia
}

\begin{abstract}
The rate of deposition of droppings from WhiteCapped Noddies Anous minutus Boie, the principal seabird nesting and roosting in the trees of Pisonia grandis $\mathrm{R}$. Br. on Heron Island, Great Barrier Reef, was measured 3 times during 1983. Deposition at ground level was extremely variable, partly because much of the material was intercepted by foliage. An average rate of deposition was about $2 \mathrm{~g} \mathrm{~m}^{-2} \mathrm{~d}^{-1}$ (dry matter), equivalent to a total input of about 45 tonnes $\mathrm{yr}^{-1}$ to the soil under the P. grandis canopy of the island. This represents the transfer of about 1.4 tonnes $\mathrm{yr}^{-1}$ of phosphorus from the surrounding waters to the island's soil where P may become stabilised in insoluble form.
\end{abstract}

Coral islands are largely dependent on the surrounding regions of the sea for influx of plant nutrients, mostly deposited by roosting and nesting seabirds. Such nutrients are crucial for the plants on coral cays, which often maintain a stable vegetation, in turn providing suitable habitats and shelter for many bird and other species. Nutrient contents of guano deposits are known for a large number of localities (e.g. Hutchinson, 1950) including some Great Barrier Reef (GBR) islands where phosphate has been mined (cf. Cribb 1979). However, little is known about the rate of input of plant nutrients by birds to islands of the GBR (cf. Heatwole et al., 1981). This report presents measurements of the input of nitrogen, phosphorus and other elements under the forest of Pisonia grandis $\mathrm{R}$. Br. (Nyctaginaceae), the major plant community on Heron Island $\left(23^{\circ} 27^{\prime} \mathrm{S}, 151^{\circ} 55^{\prime} \mathrm{E}\right)$, a coral cay about 16 ha in area. This species is closely associated with colonies of seabirds, having hooked sticky anthocarps leading to dispersal of seeds by birds, and providing nest-sites and nesting material. On Heron Island the most abundant bird nesting and roosting in the $P$. grandis trees is the White-Capped Noddy Anous minutus Boie: there were about 70,000 adults in January 1983 , and 10,000 young were raised to fledging ( $K$. Hulsman, pers. comm.). On this island Noddies nest principally in $P$. grandis (cf. Shipway, 1969).

Droppings-catchers, polyethylene bags $30 \times 45 \mathrm{~cm}$, were pegged out for 2 to $3 \mathrm{~d}$ on the ground under closed Pisonia grandis canopy. In January and Sep- tember, 10 bags were set out in a transect at $3 \mathrm{~m}$ intervals in the central $P$. grandis closed-forest (cf. Specht, 1981) to give an unbiased selection of sampling sites. Because this may not have sampled the full range of variation, 10 additional catchers were placed in pairs so that one was in a place heavily contaminated with droppings and the other was in a clean place under the same tree; the 5 trees chosen were widely separated over the island from the edge to the centre and from closed-scrub to closed-forest. The paired catchers were set out in January, May and September. Catchers were visited night and morning to remove leaf litter and debris cast over them by foraging Banded Land-Rails Rallus philippensis L. and burrowing Wedge-Tailed Shearwaters Puffinus pacificus (Gmelin). No rain fell during any of the periods, and $A$. minutus was always the principal species in the trees above all catchers. The catch was dried at $50^{\circ} \mathrm{C}$, scraped from the bags, and samples were analysed for carbon, hydrogen and nitrogen with a Heraeus CHN-Rapid analyser. Eight of the largest samples were analysed for phosphorus by the molybdenum blue method (Allen, 1974) and for cations by atomic-absorption spectrophotometry. The area covered by $P$. grandis was measured by tracing round the canopy of every tree on a map from January 1983 air-photographs.

The catch (expressed as dry-mass of material $\mathrm{d}^{-1} \mathrm{~m}^{-2}$ of ground area) was abundant at all 3 times of year (Table 1). The material consisted principally of bird droppings, but included some feathers, small pieces of plant material, coral sand and other matter. There was extreme variation between individual catchers. Undoubtedly much material is intercepted by leaves and stems in the canopy of Pisonia grandis, and the density of the foliage as well as number and activity of birds vary from time to time and place to place. Material caught on foliage may be liberated as flakes during windy conditions or washed to the ground during rain. No attempt was made in this study to estimate 
Table 1. Anous minutus. Summary of droppings caught at ground level under Pisonia grandis with nesting and roosting birds, Heron Island. Values are means in $\mathrm{g} \mathrm{m}^{-2} \mathrm{~d}^{-1} \pm$ standard error of the mean ( $\mathrm{n} d$ : not determined)

\begin{tabular}{|c|c|c|c|}
\hline & $\begin{array}{l}31 \mathrm{Jan} \text { to } \\
3 \mathrm{Feb} 1983\end{array}$ & $\begin{array}{l}30 \text { May to } \\
2 \text { Jun } 1983\end{array}$ & $\begin{array}{c}3 \text { to } 5 \text { Sep } \\
1983\end{array}$ \\
\hline $\begin{array}{l}\text { Transect }(\mathrm{n}=10) \\
\text { (Range) }\end{array}$ & $\begin{array}{c}2.2 \pm 1.2 \\
(0.002-11.6)\end{array}$ & n. d. & $\begin{array}{c}1.7 \pm 0.8 \\
(0.001-7.0)\end{array}$ \\
\hline \multicolumn{4}{|l|}{$\begin{array}{l}\text { Paired catchers: } \\
\text { Heavily contamin }\end{array}$} \\
\hline & $4.8 \pm 1.8$ & $5.0 \pm 3.7$ & $11.1 \pm 0.7$ \\
\hline $\begin{array}{l}\text { Clean place }(n=5) \\
\text { (Range, paired catch }\end{array}$ & \multicolumn{2}{|c|}{ (Range, paired catchers) } & $0.11 \pm 0.04$ \\
\hline & $(0.07-12.1)$ & $(0.01-19.6)$ & $(0.007-12.9)$ \\
\hline
\end{tabular}

Table 2. Anous minutus. Analysis of droppings caught in Jan-Feb 1983. Values expressed as percentage (by weight) of dry droppings

\begin{tabular}{|ccc|}
\hline Element & $\begin{array}{c}\text { Mean } \pm \text { Standard } \\
\text { error } \\
(\% \mathrm{w} / \mathrm{w})\end{array}$ & $\begin{array}{c}\text { Number } \\
\text { of samples } \\
\text { analysed }\end{array}$ \\
\hline $\mathrm{H}$ & $4.0 \pm 0.1$ & 20 \\
$\mathrm{C}$ & $26.2 \pm 0.6$ & 20 \\
$\mathrm{~N}$ & $14.4 \pm 1.0$ & 20 \\
$\mathrm{Na}$ & $1.8 \pm 0.1$ & 8 \\
$\mathrm{Mg}$ & $0.72 \pm 0.04$ & 8 \\
$\mathrm{p}$ & $3.1 \pm 0.2$ & 8 \\
$\mathrm{~K}$ & $2.0 \pm 0.1$ & 8 \\
$\mathrm{Ca}$ & $3.2 \pm 0.3$ & 8 \\
\hline
\end{tabular}

the amount of material caught in the tree canopy, but because of this, it is safe to conclude that the rates of dropping-fall reported here are underestimates. The material contained much carbon, nitrogen, phosphorus, potassium and calcium (Table 2), generally resembling the composition of modern guanos collated by Hutchinson (1950). It was somewhat richer in $C$ and $H$ than uric acid, the principal excretory product of the birds, and its relatively low sodium content is consistent with a mainly teleost diet for Anous minutus.

The measurements from the transect were used in the following extrapolations, since they are from an unbiased selection of sampling locations (although they did not include the very highest rates of deposition, Table 1). Noddies are numerous nearly all year, and the sampling periods represent 2 major phases of their life on Heron Island: January/February is in the egg-laying season, and in September Noddies roost in the trees but there is little breeding activity (cf. Kikkawa, 1976). These 2 sampling periods give an average dropping-catch of about $2 \mathrm{~g}$ dry matter $\mathrm{m}^{-2}$ of ground $\mathrm{d}^{-1}$, beneath Pisonia grandis canopy with Anous minutus. This leads to an annual deposition of about $0.7 \mathrm{~kg} \mathrm{~m}^{-2} \mathrm{yr}^{-1}$, and for the major plant nutrients $N, P, K$ and $M g$ of about 103,22, 14 and $5 \mathrm{~g}$ $\mathrm{m}^{-2} \mathrm{Yr}^{-1}$, respectively. $P$. grandis thrives in this situation of extremely high nutrient input, and its unique mycorrhiza (Ashford and Allaway, 1982) may function in protecting it from, or taking advantage of, the high nutrient levels. Much of the $\mathrm{N}$ and $\mathrm{K}$ is likely to be rapidly leached in the high rainfall (Heatwole et al., 1981) of Heron Island, and to exchange with the surrounding waters of the lagoon. Phosphorus, however, tends to be retained in the island rather than returning quickly to the ocean (cf. Fosberg, 1957, 1961); samples of Heron Island soil under $P$. grandis with $A$. minutus contained 930 and $1,210 \mathrm{ppm}$ bicarbonate-extractable $P$ and 1.51 and $1.76 \%$ total phosphorus. On Heron Island the $P$. grandis canopy covered about 6.3 ha, nearly all of it with Noddies, leading us to speculate that of the order of 45 tonnes (dry) of droppings would be deposited on the island each year. The 1.4 tonnes of phosphorus this contains becomes incorporated into a slowly-exchanging soil compartment, and is plainly of great importance to the island vegetation: the effect of removing it from the communities of the nearby waters remains at present a matter for speculation.

Acknowledgements. We thank M. Cole, M. Curran, M. French, G. Fogliati, P. Goulter, A. Pitman and J. Ratcliffe for assistance, and K. Hulsman for permission to quote his unpublished findings. The costs of the research were met by the Universities of Sydney and New South Wales and by the authors.

\section{LITERATURE CITED}

Allen, S. E. (ed.) (1974). Chemical analysis of ecological materials. Blackwell, Oxford

Ashford, A. E., Allaway, W. G. (1982). A sheathing mycorrhiza on Pisonia grandis $\mathrm{R}$. Br. with development of transfer cells rather than a Hartig net. New Phytol. 90: 511-519

Cribb, A. B. (1979). Terrestrial vegetation of Tryon Island. Queensland Naturalist 22: 126-132

Fosberg, F. R. (1957). Description and occurrence of atoll phosphate rock in Micronesia. Am. J. Sci. 255: 584-592

Fosberg, F. R. (1961). Description of Heron Island. Atoll Res. Bull. 82: 1-4

Heatwole, H., Done, T., Cameron, E. (1981). Community ecology of a coral cay. Junk, The Hague

Hutchinson, G. E. (1950). Survey of contemporary knowledge of biogeochemistry. 3. The biogeochemistry of vertebrate excretion. Bull. Am. Mus. Nat. Hist. 96: 1-554

Kikkawa, J. (1976). The birds of The Great Barrier Reef. In: Jones, O. A., Endean, R. (ed.) Biology and geology of coral reefs, Vol. III, Biology 2. Academic Press, New York, p. 279-341

Shipway, A. K. (1969). The numbers of terns and shearwaters nesting on Heron Is. in 1965. Emu 69: 108-109

Specht, R. L. (1981). Foliage projective cover and standing biomass. In: Gillison, A. N., Anderson, D. J. (ed.) Vegetation classification in Australia. CSIRO and ANU Press, Canberra, p. 10-21

Accepted for printing on June 22, 1984 